\title{
Distribution, autecology, genetic characterization, and conservation of the Western Mediterranean endemic dragonfly Orthetrum nitidinerve (Selys, 1841): insights from Italy
}

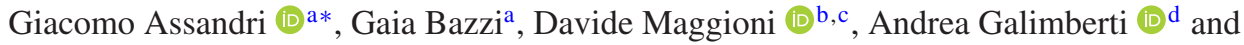 \\ Bernd Kunz ${ }^{\mathrm{e}}$ \\ ${ }^{a}$ Area Avifauna Migratrice, Istituto Superiore per la Protezione e la Ricerca Ambientale (ISPRA), Ozzano \\ dell'Emilia, Italy; ${ }^{b}$ Department of Environmental and Earth Sciences (DISAT), University of Milano - \\ Bicocca, Milan, Italy; ${ }^{c}$ Marine Research and High Education (MaRHE) Center, University of Milano - \\ Bicocca, Faafu Magoodhoo, Maldives; ${ }^{d}$ ZooPlantLab, Department of Biotechnology and Biosciences, \\ University of Milano - Bicocca, Milan, Italy; ${ }^{e}$ Hauptstraße 111, 74595, Langenburg, Germany
}

(Received 4 July 2020; final version received 22 September 2020)

\begin{abstract}
Aquatic macroinvertebrates are a primary component of freshwater ecosystems and one of the most threatened by anthropogenic pressures. Among them, dragonflies are a charismatic group of growing scientific and social interest. However, little is known about the natural history of several species. One paradigmatic example is the declining Orthetrum nitidinerve, a Western Mediterranean endemic anisopteran. We reviewed published and new data on this species, addressing distribution, autecology, and conservation (with a focus on Italy), and provide its first genetic characterization and phylogenetic placement within the genus. In Italy, the species is known from 50 sites so far (only 17 breeding populations) located in Sardinia and Sicily (1841-2019, only 22 from 1990 onward). Records from continental Italy are due to misidentification. The flight period in Italy spans between May and September. Habitat consists of permanent freshwater (mostly helocrene sources, seepages, and small brooks), slow-flowing, shallow, with muddy bottom deposits at elevation from the sea level up to $1000 \mathrm{~m}$ asl. All the breeding populations are found in open and sunny landscapes, almost invariably in extensive pasturelands. The species has strongly declined in Sicily, whereas several large populations still occur in Sardinia. The major threats identified so far are agriculture and grazing intensification or abandonment and drought/source desiccation determined by water overexploitation and climate change. The first ever provided mitochondrial COI barcode and ITS nuclear sequences allowed a first tentative phylogenetic placement of the species as a sister group of the $O$. brunneum/O. lineostigma lineage.
\end{abstract}

Keywords: freshwater invertebrates; global change; phylogeny; Odonata; Sardinia; Sicily

\section{Introduction}

Freshwater environments are among the most threatened ecosystems worldwide and there is an increasing need to improve our ability to assess their biodiversity and to address how it changes over time in response to human-induced perturbations (Collen et al., 2014; Darwall et al., 2018). Considering the multifaceted communities inhabiting freshwater ecosystems, macroinvertebrates are among the most endangered faunal groups, and this is even more worrying considering that

*Corresponding author. Email: giacomo.assandri@gmail.com 
they provide invaluable ecosystem functions and services (Borgwardt et al., 2019; May, 2019). At the same time, they are most influenced by global change and environmental perturbation (e.g. land-use change, climate change, pollution, and introduction of alien species; Batzer \& Boix, 2016; Strayer, 2006; Termaat et al., 2019).

Among freshwater invertebrates, a group of growing scientific and social interest is that of odonates. In Europe, 145 species of dragonflies and damselflies are known to occur so far (Boudot \& Kalkman, 2015; López-Estrada, Fernández, Cardo-Maeso, Teruek Montejano, \& Diaz-Martinez, 2020; Viganò, Janni, \& Corso, 2017), and their appeal to amateur naturalists and the public increased considerably in the last three decades. This trend has led to a notable increase of knowledge on their distribution and ecology (Kalkman et al., 2018). Notwithstanding this, there are several species which are poorly known, especially concerning their distribution, autecology, and conservation status. An emblematic case is the Western Mediterranean endemic Orthetrum nitidinerve (Selys, 1841).

This dragonfly species was described (as Libellula nitidinervis) by Edmond de Sélys Longchamps in 1841 (Selys, 1841) from specimens collected by Vittore Ghiliani in Sicily and conserved at the Zoological Museum of the University of Torino (now Museo Regionale di Scienze Naturali), where they were shown to the famous Belgian odonatologist by the former curator of the collection, Giuseppe Gené, in 1840 (Selys \& Hagen, 1850). Nowadays, this species is considered a Western Mediterranean endemic, distributed in the Maghreb, approximately from western Morocco to north-eastern Libya, where it is relatively common in the Mediterranean belt and scarcer toward the Sahara. In Europe, it is reported to occur scattered in the Iberian Peninsula, Sardinia, Sicily, and very locally in mainland Italy (Kalkman \& Garrigos, 2015). Occasional vagrant individuals were recently reported from the Sicilian channel (Corso et al., 2012) and Malta (Sciberras \& Sammut, 2013; Sciberras, Sciberras, \& Kunz, 2010). In Iberia, it is mainly found in the south-west, along the eastern coast, and in the Ebro valley (Kalkman \& Garrigos, 2015); most data refer to isolated individuals and the few known reproductive populations were only recently discovered (Marquez-Rodriguez, 2014; Márquez-Rodríguez \& Ferreras-Romero, 2013; Torralba Burrial, Ocharan Larrondo, Cano Villegas, Outomuro Priede, \& Azpilicueta Amorín, 2011). The species is found at elevations up to 2020m (in North Africa; Kalkman \& Garrigos, 2015). In recent decades, O. nitidinerve declined significantly (by about $30 \%$, when its occurrences in the periods 1980-1989 and 1990-2000 are compared) across its European range (Kalkman \& Garrigos, 2015), and thus it is considered as "vulnerable" according to IUCN criteria (Kalkman et al., 2010); however, it was assessed as "least concern" considering its whole Mediterranean range (Riservato et al., 2009). In Spain, it is considered "vulnerable" (Torralba Burrial et al., 2011). In Italy, it seems to have stable populations in Sardinia, possibly declining in Sicily, and it seems to have disappeared from mainland Italy (last observations in 1987). The few records referred to the mainland Italian populations, however, need confirmation (Riservato, Festi, et al., 2014; Surdo, 2017), although they are included in the Atlas of the European dragonflies and damselflies (Kalkman \& Garrigos, 2015). Very few updated data exist on its distribution and population size, thus, it was assessed as "data deficient" in the Italian IUCN Red List (Riservato, Fabbri et al., 2014). In contrast to other European Orthetrum species, knowledge on the biology, ecology and behaviour of $O$. nitidinerve is very scarce or even absent and no genetic information is currently available in public international databases (Khelifa, Zebsa, Kahalerras, \& Mahdjoub, 2012; Márquez-Rodríguez \& Ferreras-Romero, 2013). The authors of the European IUCN red list of dragonflies stressed the importance of gathering additional data on the distribution and habitat requirements of the species (Kalkman et al., 2010).

This study aims to fully review the current knowledge on $O$. nitidinerve using Italy as a model of investigation to be replicated in other Mediterranean countries and for other species having similar conservation issues. Specifically, we present data on: (i) its distribution (including altitudinal distribution) in Italy, based on all available published and unpublished data, and thoroughly 
discussing the unclear records referring to its presence in the Italian peninsula; (ii) several aspects of its autecology, including habitat preferences and phenology; (iii) the anthropogenic pressures likely impacting the species; and (iv) a genetic characterization, including data on the divergence from other congenerics and its phylogenetic placement within the Orthetrum genus. We strongly believe that these new data can serve as a basis to further develop monitoring scheme on this poorly studied species and, possibly, to design adequate measures for its conservation.

\section{Materials and methods}

Data considered for this review were obtained from a thorough revision of the available literature and several unpublished data including personal observations, repositories of citizen science projects (consulted: Inaturalist, Gbif, Ornitho.it, Observation.org; not all contained useful data), and personal communication from colleagues. Additionally, a few unpublished data come from scientific collections. On 30 September 2019 we visited the collection "A. Costa" at the "Museo Zoologico dell'Università" in Naples (Italy) to check several specimens there conserved.

All data were scrutinized and validated and, when possible, georeferenced. Elevation, when not specifically reported, was obtained based on coordinates from a DTM $20 \times 20 \mathrm{~m}$ grid. Four levels of geographical accuracy were available: precise location (the coordinates were assessed by the observer in the fields by using a GPS or defined lately from GIS software; their accuracy is less than $1 \mathrm{~km}$, generally much less), toponym (only a toponym was available, however, they were quite accurate and allow an uncertainty lesser than $3 \mathrm{~km}$ ), generic toponym (toponym was given but it was inaccurate, allowing an accuracy between 3 and $25 \mathrm{~km}$ ), generic (a few old records referred to wide geographical areas, impossible to be georeferenced; e.g. "Sicily"). The first three categories were used to map the distribution of $O$. nitidinerve in Italy. The presence of breeding (or possibly breeding) population was assessed by the following indicators: occurrence of larvae or exuviae, tenerals, mating pairs, oviposition behaviour, repeated presence of more than one adult in appropriate habitat at different times of the same year. The simple presence of adults was not considered evidence of a breeding population (although this could not be excluded). Records were additionally classified according to two time periods (before 1990 and from 1990 onwards), for comparability with the threshold used in Boudot and Kalkman (2015). We classified the sites where the breeding populations occurred according to broad habitat categories. This was possible only for precise locations or when details were provided by the author of the records.

We provide a list of the anthropogenic pressures which have likely impacted the species. Although a specific assessment of threats affecting the species in Italy is lacking, we derived these data from literature and personal observations. The pressures classification was based on the "List of pressures and threats" provided for the reporting under Article 17 of the "Habitat" Directive (release 2.4, 7 May 2018; available online at http://cdr.eionet.europa.eu/help/habitats_art17).

\section{Genetic analyses}

In order to provide a genetic characterization of $O$. nitidinerve, as well as to infer its possible phylogenetic placement within the genus, two datasets were assembled. The first dataset (DS1) consisted of all available Orthetrum COI sequences mined from GenBank and the BOLD Systems. This dataset also includes DNA barcode sequences generated for a recent survey of Italian Odonata (Galimberti et al., 2020) and deposited as reference DNA barcode data in the BOLD Systems platform, among 
which two were referred to $O$. nitidinerve (identification numbers: ZPLOD661-20 and ZPLOD663-20, collected in Sardinia on July 2019; see specimen webpages available at https://www.boldsystems.org/index.php/MAS_Management_DataConsole?codes = ZPLOD for additional details). Sequences with insertions/deletions or shorter than $500 \mathrm{bp}$ were discarded, and a total of 206 sequences belonging to 30 nominal species were assembled, including Sympetrum vulgatum (Linnaeus, 1758) as an outgroup (SM1). The second dataset (DS2) included Orthetrum specimens for which two or three molecular markers (i.e. mitochondrial COI, $16 \mathrm{~S}$ rRNA, nuclear ITS region) were available, and consisted in 27 specimens belonging to 15 species, including Sympetrum fonscolombii (Selys, 1840) and Lestes sponsa (Hansemann, 1823) as outgroups (SM2). ITS sequences from the same $O$. nitidinerve samples (i.e. ZPLOD661-20 and ZPLOD663-20) were obtained as follows.

For each sample, the complete ITS region and part of its flanking regions (for a total of $714 \mathrm{bp}$ ) were amplified with primers ITSF and ITSR (Weekers, De Jonckheere, \& Dumont, 2001). PCR amplification conditions were the same described by Weekers et al. (2001), while PCRs were conducted as in Mazzamuto et al. (2016) and sequencing conducted bi-directionally at Eurofins Genomics (Milan, Italy), with the same PCR primers. Consensus sequences were obtained editing electropherograms using BioEdit 7.2 (Hall, 1999). Sequences were deposited in GenBank under accession number MT322242 and MT322243 for ZPLOD661-20 and ZPLOD663-20 respectively. All sequences were aligned using MAFFT 7.110 (Katoh \& Standley, 2013) using the E-INS-i option. Subsequently, COI sequences were checked for the presence of open reading frame using Geneious 7.1.3 and ITS sequences were processed through Gblocks (Castresana, 2000; Talavera \& Castresana, 2007) using the "less stringent" settings to remove ambiguously aligned regions. Identical sequences in the DS1 were collapsed in haplotypes using FaBox (Villesen, 2007), whereas single-locus alignments of DS2 were concatenated using Mesquite 3.61 (Maddison \& Maddison, 2018) to obtain a multi-locus matrix. Appropriate partition schemes and models were determined using JModelTest 2 (Darriba, Taboada, Doallo, \& Posada, 2012) for DS1 and PartitionFinder 2 (Lanfear, Calcott, Ho, \& Guindon, 2012) for the DS2, using all the available information criteria. Phylogenetic inference analyses were performed for both datasets using Bayesian inference (BI) and maximum likelihood (ML). BI analyses were performed using MrBayes 3.2.6 (Ronquist et al., 2012): four parallel Markov Chain Monte Carlo runs (MCMC) were run for $10^{7}$ generations, trees were sampled every 1000th generation, and burn-in was set to $25 \%$. Maximum likelihood trees were built with RAxML 8.2.9 (Stamatakis, 2014) using 1000 bootstrap replicates. All analyses were run on the CIPRES server (Miller, Pfeiffer, \& Schwartz, 2010).

Additionally, DS1 was also used to calculate intra- and inter-specific genetic distances using MEGA X (Kumar, Stecher, Li, Knyaz, \& Tamura, 2018). Specifically, distances were calculated as Kimura-2-parameter distances with 1000 bootstrap replicates.

\section{Results and discussion}

\section{Italian distribution}

This review is based on 80 records (40 derived from literature, and 40 unpublished) encompassing a period between 1841, when the species was first described (Selys, 1841), and 2019. Of those, five should be considered erroneous (see below) and four have a very low geographical accuracy (generic localities). Remaining records are referred to a total of 50 different sites (22 precise locations, nine toponyms, 19 generic toponyms), of which 17 are confirmed or likely breeding sites. All reliable records refer to Sardinia and Sicily only. Thirty-three occur in Sardinia: 13 before 1990 (four breeding sites) and 20 from 1990 onward (eight breeding sites, of 
which one is confirmed from the previous period). Seventeen occur in Sicily: 15 before 1990 (five breeding sites) and only two from 1990 onward (with no confirmed reproduction) (Figure 1). The first unequivocal evidence (i.e. observed emergence) of the reproduction of the species in Italy dates back to the 1970s and it is referred to Sicily (Bucciarelli, 1977; Pavesi M., pers. com.). Kalkman and Garrigos (2015) claimed that since 1990, only 56 occurrence localities of O. nitidinerve have been known so far in Europe. This study report 22 localities in Italy since 1990, but only eight confirmed breeding populations are known to date (all located in Sardinia).

In Sicily the species has not been reported since 1985, excluding a record referred to a vagrant individual observed at Lampedusa Island in 2010 (Corso et al., 2012) and one individual reported in 2017 near Castelvetrano, with no subsequent observations or confirmations of a breeding population, despite the habitat appearing suitable and being thoroughly surveyed in the following years (Surdo, 2017). The current rarity in Sicily seems to suggest a major decline of the species in this island, further supported by the fact that the island was subjected to several faunistic surveys in recent years, which also included resurveys of the past occurrence sites (Pavesi M., Corso A., pers. com.). The record from Lampedusa Island, along with several recent records from Maltese islands (Sciberras et al., 2010; Sciberras \& Sammut, 2013), strengthen the hypothesis that the species is more mobile than previously believed and it can cross open sea stretches, keeping the debate open whether its colonization of Sardinia and Sicily dates back to the last Ice Age or is due to subsequent colonization events from North Africa (Sciberras et al., 2010).

Conversely, Sardinia still harbours a few, but apparently healthy, populations of the species, which were mostly discovered from 1990 onward, thanks to the thorough fieldwork of one of the authors (BK). Old records are difficult/impossible to verify because of their low geographical accuracy. As a consequence, we were only able to verify that a population has maintained itself in an area between the two periods (observed in 1972 and 2013). The apparent reduction suggested by Bucciarelli, Galletti, and Pavesi (1983) in the northern part of the island seems to be not supported by our data.

Considering mainland Italy, the first record of O. nitidinerve was due to Bentivoglio (1905), who examined the "Collezione entomologica meridionale" conserved at the Museo Zoologico della Regia Università in Naples (today "A. Costa" collection, from the name of its first curator) in 1904. In this collection, Bentivoglio found an O. nitidinerve specimen from Naples. Subsequent authors clarified that Bentivoglio's odonate identifications were often scarcely reliable (Conci \& Galvagni, 1948; Conci \& Nielsen, 1956); however, the attribution of this specimen to $O$. nitidinerve was confirmed by other authors who reviewed the same collection, specifically Consiglio (1952), who clarified that it was a female, and D'Antonio (D'Antonio, 1985, 1989). Cesare Nielsen studied the "A. Costa" collection in 1937 and did not report the Naples specimen. It is not clear whether this was because he focused on the Sardinian fauna (Nielsen, 1940), or because he found the determination to be erroneous. However, in his seminal work on the Italian odonatofauna (Conci \& Nielsen, 1956), the presence of $O$. nitidinerve in mainland Italy was cited only based on the above-cited study of Consiglio.

Our recent visit to the "A. Costa" collection allowed us to confirm the existence of three Orthetrum specimens attributed to $O$. nitidinerve; however, the one from Naples (labelled as Consiglio det.) resulted in being a female Orthetrum brunneum (Fonscolombe, 1837), whereas the other two females, collected by Costa in Sardinia at the end of the XIX century, were both correctly identified.

The misidentified individual from "A. Costa" collection was not the only mention of $O$. nitidinerve from mainland Italy. All the other records also refer to Campania region and can be listed as follows:

(1) Two males, May 1928, Portici (NA). Conserved in the Museo dell'Istituto di Entomologia Agraria di Portici - Università di Napoli (D’Antonio, 1985). However, these specimens 


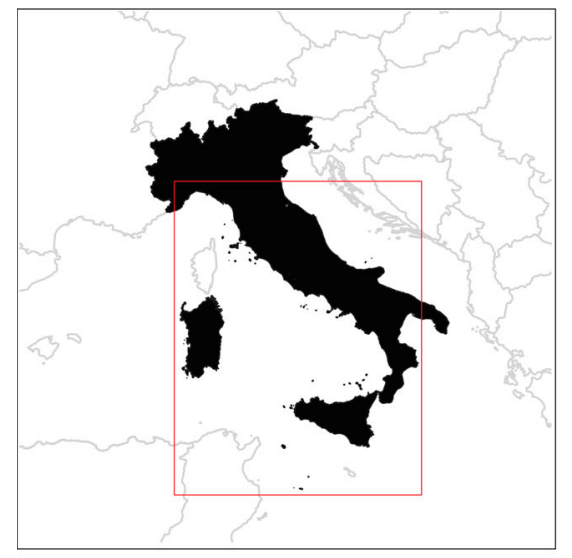

- breeding pop. (1990 onward)

$\square$ breeding pop. (before 1990)

- simple occur. (1990 onward)

- simple occur. (before 1990)

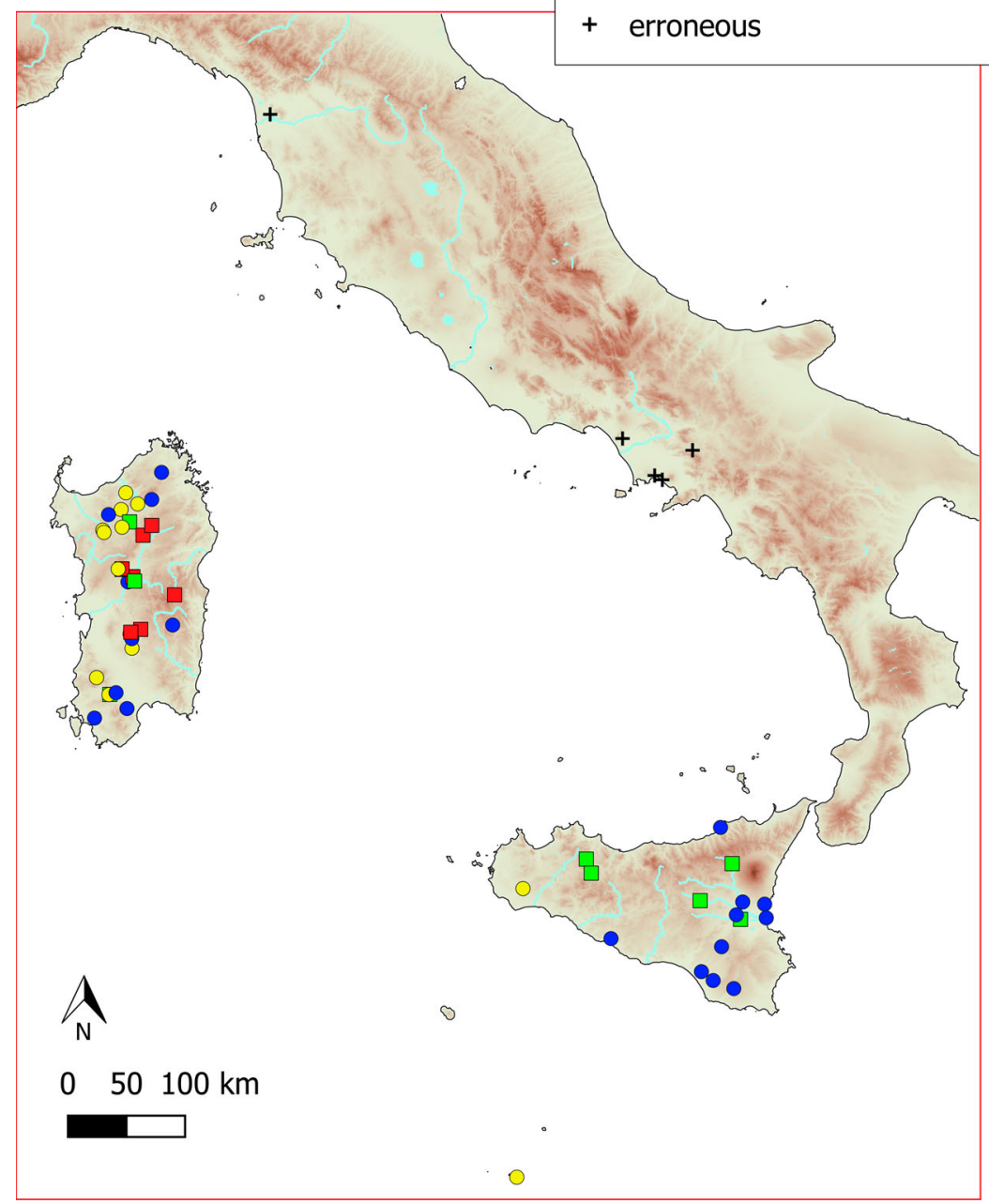

Figure 1. Occurrence and breeding populations sites of Orthetrum nitidinerve in Italy. The inset shows in details Sardinia, Sicily and Southern Italy. Data span from the species description in 1841 to 2019 . N $=50$ sites (plus 5 erroneous). 
were not mentioned again in a subsequent revision of this collection by the same author (D’Antonio, 1997).

(2) Two males, one female, 21 June 1987, Lago di Falciano (CE) (D’Antonio, 1987).

(3) Three males, five females, 25 August 1987, Loc. Varrettelle, San Martino Valle Caudina (AV) (D'Antonio, 1987). These last two records were due to misidentification and all refer to Orthetrum coerulescens (Fabricius, 1798) as recently clarified by D'Antonio (pers. com.).

A Tuscany XIX century record (S. Giuliano, Pisa; Spagnolini \& Ragazzi, 1879) is not reliable and has already been excluded by other authors (e.g. RIservato, Festi et al., 2014b). This considered, no reliable $O$. nitidinerve records exist from continental Italy.

In Italy, O. nitidinerve was reported from the sea level (several localities) up to $1100 \mathrm{~m}$ (Monte Arqueri, Sardinia; Nielsen, 1940), although this elevation refers to the top of the mountain and the favourable habitat for the species is likely to occur around $1000 \mathrm{~m}$. In Sardinia, O. nitidinerve appears to avoid coastal areas, favouring the interior. Confirmed breeding populations occur between 70 and $965 \mathrm{~m}$ (mean $\pm \mathrm{SD}=394 \pm 310 \mathrm{~m}, \mathrm{~N}=12$ ). Conversely, in Sicily, most of the records refer to an elevation below $100 \mathrm{~m}$ and breeding populations occurred between 40 and $610 \mathrm{~m}$ (mean $\pm \mathrm{SD}=389 \pm 240 \mathrm{~m}, \mathrm{~N}=5$ ) (Figure 2) .

\section{Phenology}

The flight period of the species in Italy spans between May and September, although the great majority of the available records are comprised between June and August (Figure 3). Elsewhere in its range, the flight period of the species can be very wide, spanning from the second half of March to the first half of November, with reduced variability between North Africa and Spain (Kalkman \& Garrigos, 2015), but, apparently, much local variability (e.g. Khelifa et al., 2013; Márquez-Rodríguez \& Ferreras-Romero, 2013).

Very few data exist on the voltinism of the species. In Spain, the record of a newly emerged female in the first half of September indicates that $O$. nitidinerve is probably able to produce a second generation under favourable conditions, thus exhibiting partial bivoltinism (MárquezRodríguez \& Ferreras-Romero, 2013). This is also likely for North Africa, with the observation of emergence in September and October (Jödicke et al., 2000). Unstandardized observations in Sardinia seem to suggest a similar pattern, with individuals emerging in late May-June and others from mid-August (see for example Figure 4e, f). However, the possibility of late emerged individuals cannot be ruled out without a specific study on the voltinism of the species.

\section{Habitat preferences}

Habitat characteristics were available for 11 of the 17 breeding sites, namely for almost all those located in Sardinia, where currently the only Italian stable populations of the species are known to occur.

Three main habitat types appear to be used by $O$. nitidinerve in Sardinia: (i) sources and seepages (27.5\%); (ii) slow-flowing small brooks (45\% of the occurrences); (iii) rivers $(27.5 \%)$.

Sources/seepages are often very small microhabitats $\left(<15 \mathrm{~m}^{2}\right)$. The water spilling from the soil (helocrene source) can originate small swamps or slow-flowing rivulets, which get lost after a few metres (Figure 5a). Sources are often intercepted to create fountains or animal troughs and the species can colonize the swampy area formed by the water spilling from these artificial points of water (Figure 5b).

Small (often $<1 \mathrm{~m}$ wide), very slow-flowing brooks are key habitats for the species as they often harbour large populations (Figure 5c). The single recent record from Sicily, although not referred to a confirmed breeding population, can be classified in this habitat category (Surdo, 


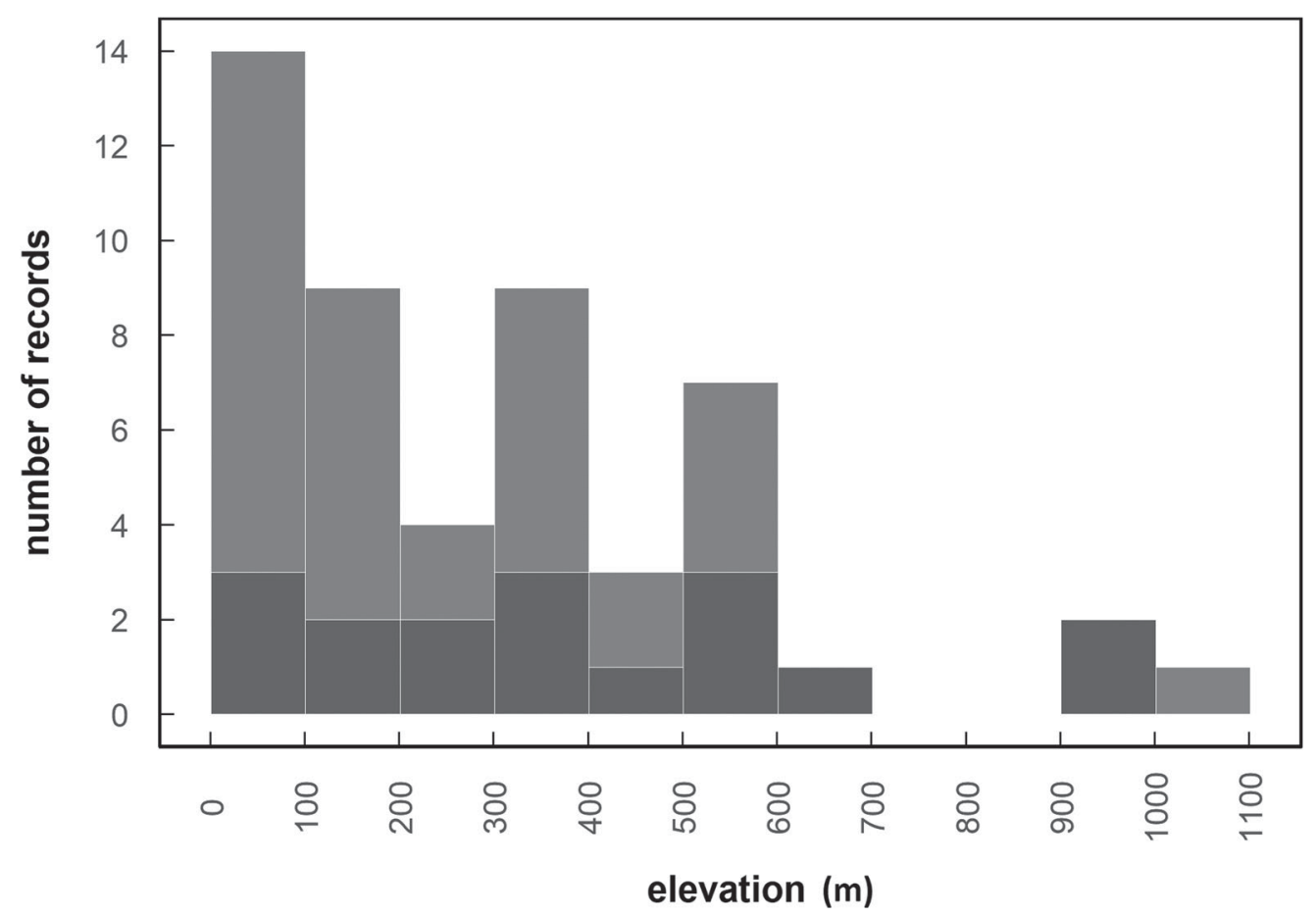

Figure 2. Altitudinal distribution of Orthetrum nitidinerve in Italy. Breeding (dark grey) and simple occurrence (light grey) sites are distinguished. $\mathrm{N}=50$ sites.

2017). However, rivers do not appear to be an optimal habitat for the species. We have evidence for two rivers in Sardinia: Rio Cixerri, a small river in the south of the island, about $2 \mathrm{~m}$ wide, and Rio Tirso, a medium-sized river, about $20 \mathrm{~m}$ wide, where teneral individuals were observed (BK, pers. obs.). Referring to this last site, it cannot be completely ruled out that reproduction occurred nearby, along a lateral stretch.

Overall, common features of most of the habitats colonized by the species are permanent, slow-flowing, even trickling freshwater, shallow $(0-5 \mathrm{~cm}, 20-30 \mathrm{~cm}$ in pools), and with muddy bottom deposits, in which the larvae are found. Often, a limited water level oscillation is favoured, probably because this reduces the washing of the mud out of the brook's bed.

All the breeding populations are found in open and sunny landscapes, almost invariably in extensive pasturelands. We observed that animal trampling (if not intensive) can create pools of various size that are exploited as larval habitats. In Sardinia, Calopteryx haemorrhoidalis (Vander Linden, 1825), Ischnura genei (Rambur, 1842), Orthetrum coerulescens anceps (Schneider, 1845), Orthetrum brunneum (Fonscolombe, 1837), and Crocothemis erythraea (Brullé, 1832) were the commonest accompanying species.

Although referred to a limited number of breeding populations, these data considerably increase knowledge on the habitat preferences of the species in Europe, for which there is little information available (De Knijf \& Demolder, 2010; Kalkman et al., 2010). Our results appear consistent with those of other authors which recently suggested that the species seems to reach the highest density in small, shallow, and slow-flowing watercourses (e.g. brooks, springs, seepages) in open areas with an abundance of grassy vegetation, which become marshy due to water infiltration (Kalkman \& Garrigos, 2015; Khelifa et al., 2013; Prunier, 2015).

Kalkman et al. (2010) suggested that in Europe the species is associated with major river systems; however, recent evidence from Iberia and our observations in Sardinia suggest that it is 


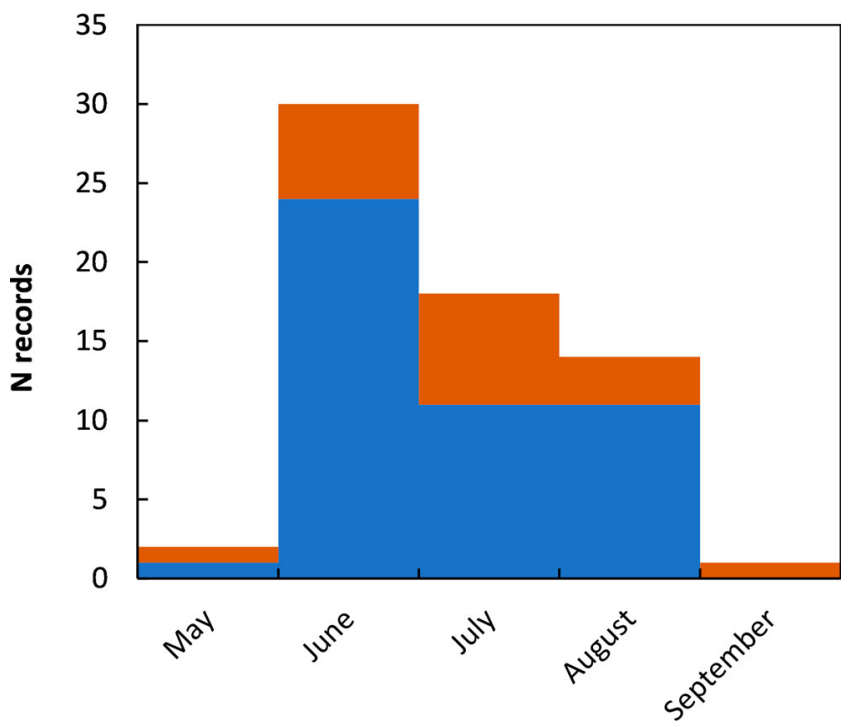

Figure 3. Flight period of Orhtetrum nitidinerve in Italy. Colours refer to different regions (blue: Sardinia; brown: Sicily). $\mathrm{N}=65$ records.

likely that small streams, helocrene sources, and seepages are the main habitat for this species (Gaona \& Enrique, 2015; Márquez-Rodríguez \& Ferreras-Romero, 2013). Possibly its occurrence at large rivers depends on either regular re-colonization or vagrancy from core habitat (Kalkman \& Garrigos, 2015). Prunier (2015) found a population in a very artificialized and disturbed rivulet in southern Spain; however, we have no evidence of this kind referred to Italy.

In one case, we observed a female ovipositing in a stagnant drinking puddle next to a "typical" breeding area (Giara di Gesturi, GA \& GB, pers. obs.), and although some records from stagnant waters are available elsewhere, it is doubtful that the species can reproduce at sites that are stagnant throughout the year (Kalkman \& Garrigos, 2015), in particular, if subjected to desiccation.

\section{Anthropogenic pressures and threats}

Orthetrum nitidinerve is considered a declining species across Europe. The causes of its decline are suspected to include the decrease in the overall quality of running waters (Kalkman et al., 2018), and, specifically, desiccation due to rainfall deficit (possibly connected with climate change), regulation of rivers, lowering of the water table due to water extraction, water pollution, draining of springs, streams, seepages, wetlands, and trampling by livestock (Kalkman \& Garrigos, 2015; Torralba Burrial et al., 2011). However, a detailed assessment of pressures impacting this species is lacking.

In Table 1 we list the pressures/threats which have been impacting $O$. nitidinerve in Italy. As most of its breeding habitats occur in agricultural landscapes (as reported from other parts of Europe; Márquez-Rodríguez \& Ferreras-Romero, 2013; Prunier, 2015), the effects of agricultural practices (and their modifications) are expected to play a crucial role in the conservation of this species. This dragonfly appears to be strictly dependent on grassland-dominated landscapes maintained for livestock. An intermediate level of grazing is likely to favour the species, keeping breeding freshwater habitats open and unshaded. The cessation of grazing determines the rapid development of the secondary succession, with a consequent increase of Mediterranean shrubland and forest cover, which are mostly unsuitable ecosystems for the species. Possibly, 

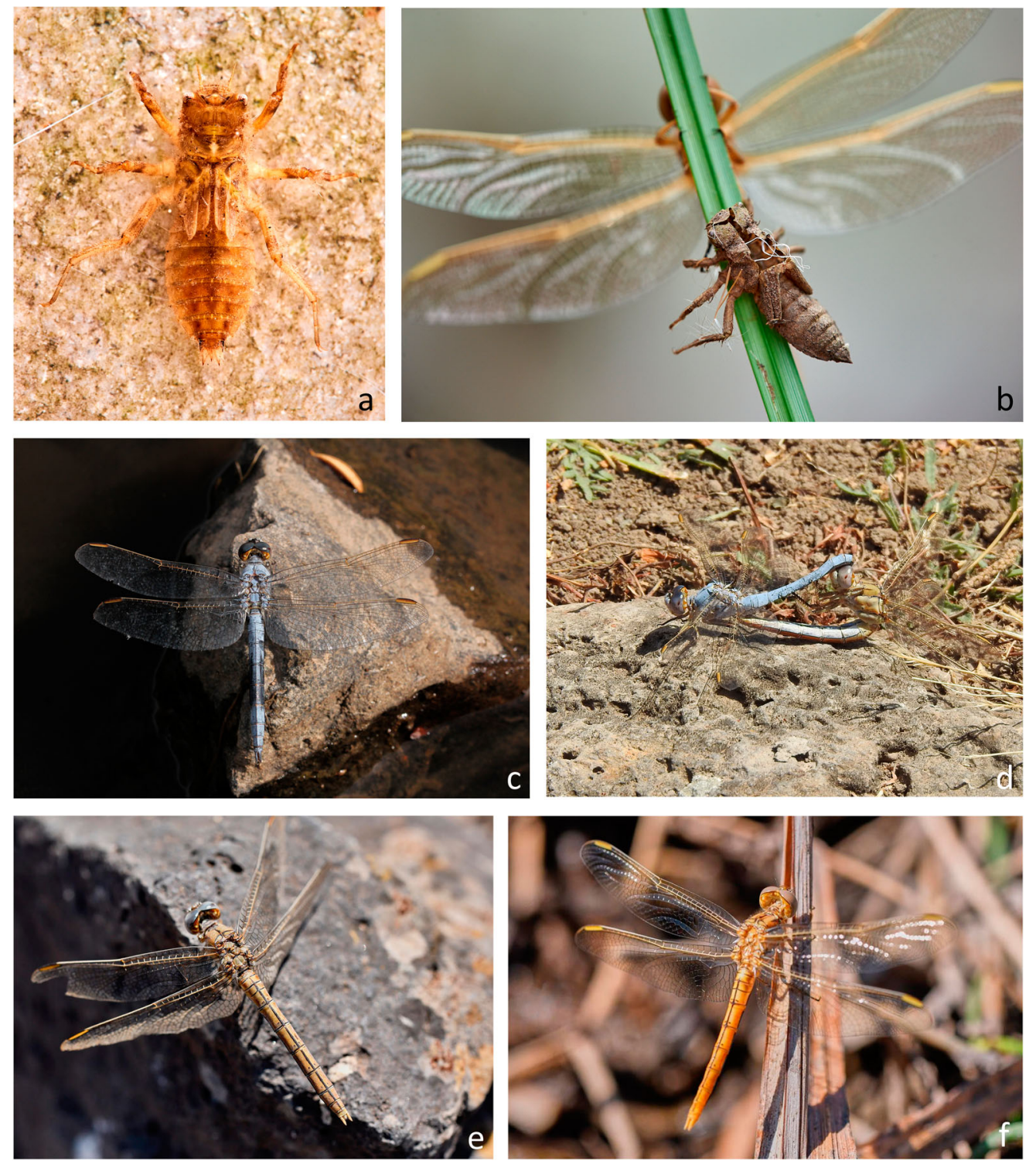

Figure 4. Documentations of Orthetrum nitidinerve in Italy. (a) Last instar larva; (b) exuvia, and freshly emerged imago (Riu Cuguttu, Bortigali, Sardinia, 12 June 2011); documentations of larvae, exuviae, and emergence are very rare in Europe; (c) mature male with characteristic evidence of mating on the abdomen (Riu Cuguttu, Bortigali, Sardinia, 8 July 2019); (d) mating pair (Funtana S'Ala de Mangianu, Genuri, 13 July 2019); (e) old (at least few weeks) female and (f) teneral female co-occurring the same day (Funtana S'Ala de Mangianu, Genuri, 26 August 2016). Photos: G. Bazzi, B. Kunz, G. Assandri.

just a moderate rate of abandonment (e.g. cessation of shrubs/tree control along brooks and rivulets) is very likely to impact this dragonfly in the short term. In this, $O$. nitidinerve is similar to the majority of Mediterranean species belonging to different taxonomic groups, which are strongly impacted by the abandonment of the traditional husbandry (Plieninger, Hui, Gaertner, \& Huntsinger, 2014; Sirami, Brotons, Burfield, Fonderflick, \& Martin, 2008).

On the other hand, intensive livestock systems, and consequent overgrazing, in the long run, are likely to impact the species, due to erosion, nitrification/eutrophication, water reduction on 

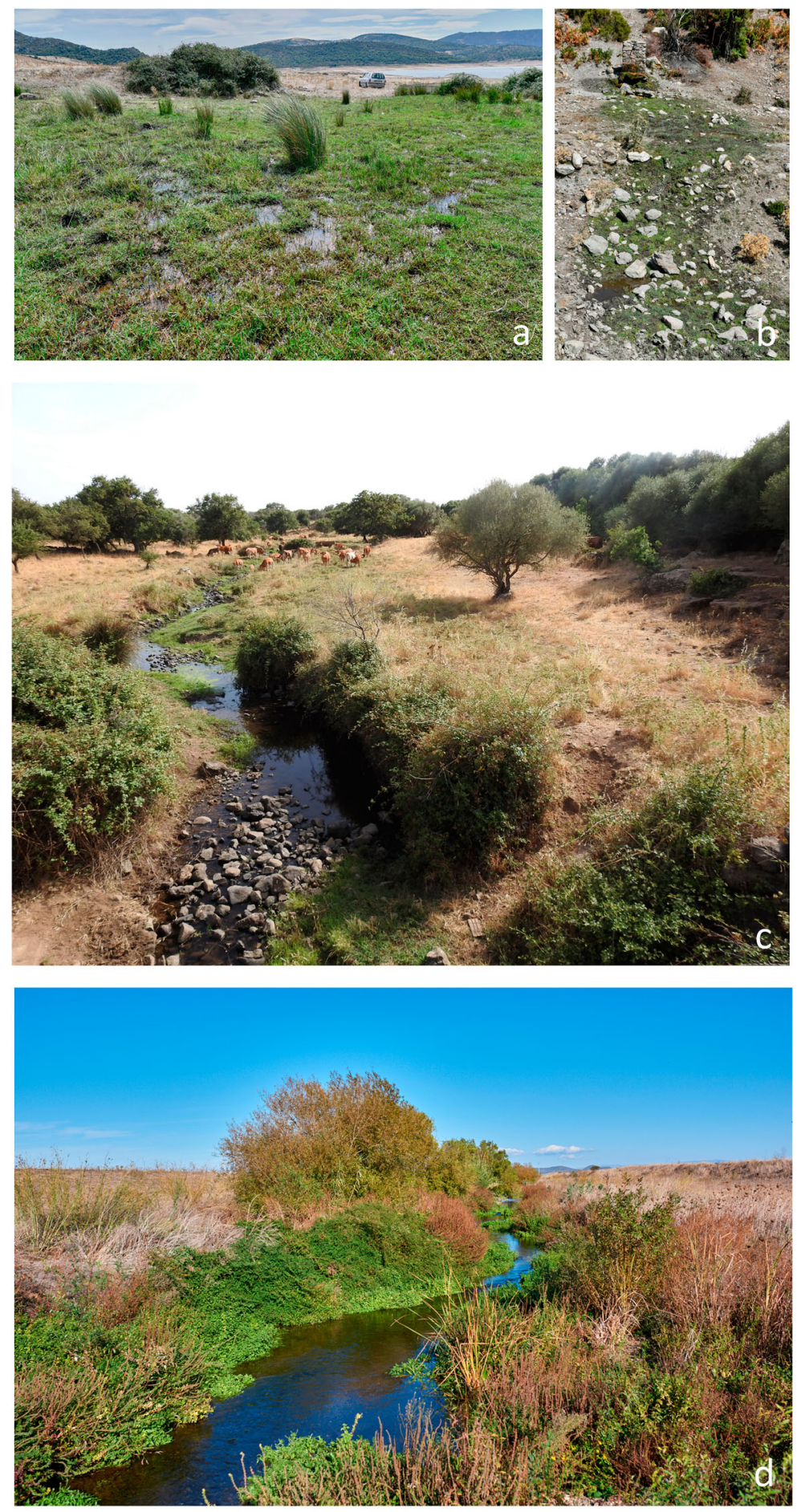

Figure 5. Examples of breeding habitat of Orthetrum nitidinerve. (a) Source with seepage creating a swampy area (helocrene source) (north shore of Lake Lerno, Pattada, Sardinia). (b) Fountain with water spilling creating a microhabitat favourable for reproduction (bridge over Erriuè sa Goda, Villanova Strisaili, Sardinia, 22 August 2016). (c) Slow-flowing small brooks (Riu Cuguttu, Bortigali, Sardinia, 8 July 2019). (d) Small river. At this site a breeding population was confirmed in 1990 when it had a less vegetated appearance; subsequently, there were only occasional records (Rio Cixerri, Siliqua, Sardinia, 2 November 2017). Photos: B. Kunz, G. Assandri. 
Table 1. List of pressures/threats which have impacted Orthetrum nitidinerve in Italy. Codes and names were derived from the "List of pressures and threats" provided for the reporting under Article 17 of the "Habitat" Directive.

\begin{tabular}{ll}
\hline Code & \multicolumn{1}{c}{ Pressure/threat } \\
\hline A02 & $\begin{array}{l}\text { Conversion from one type of agricultural land use to another } \\
\text { Removal of small landscape features for agricultural land parcel consolidation (hedges, } \\
\text { stone walls, rushes, open ditches, springs, solitary trees, etc.) } \\
\text { Abandonment of grassland management (e.g. cessation of grazing or mowing) }\end{array}$ \\
A06 & $\begin{array}{l}\text { Intensive grazing or overgrazing by livestock } \\
\text { A09 }\end{array}$ \\
F01 & Conversion from other land uses to housing, settlement or recreational areas \\
F03 & Mixed source pollution to surface and ground waters (limnic and terrestrial) \\
J01 & Abstraction from groundwater, surface water or mixed water \\
K01 & Drainage \\
K02 & Modification of hydrological flow \\
K04 & Physical alteration of water bodies \\
K05 & Droughts and decreases in precipitation due to climate change \\
N02 &
\end{tabular}

pasturelands, and direct impact on breeding micro-habitats (i.e. intensive trampling, desiccation of water points). Grazing intensification is a facet of a more general trend that agriculture is following in the Mediterranean basin and worldwide, that of intensification of agricultural practices (Caraveli, 2000; Sokos, Mamolos, Kalburtji, \& Birtsas, 2013). Intensification is likely to have impacted $O$. nitidinerve by an overall simplification of the landscape (i.e. removal of micro landscape features such as springs and seepages) and a transition from a grassland/steppe extensive agroecosystem to an intensive farming one (e.g. dominated by croplands). Additionally, water pollution and eutrophication due to the drift of pesticides and fertilizers from agricultural fields to freshwater habitats have likely a strong negative effect on the species.

Similarly, urbanization and development of commercial/industrial/recreational areas are direct threats determining habitat loss by drainage and indirect effects (e.g. pollution of freshwater habitats). In Sardinia, the human population density is less than half if compared with that of Sicily, and thus the impact of urban development is likely to have been lower. This may explain the different fate of the species in these two islands.

Increasing demand of water for agricultural, civil, and industrial uses is expected to harshly impact aquatic species, by determining spring drying, strong water level perturbation, hydrological flow modification, and physical alteration of watercourses. According to the habitat preference delineated in this study, $O$. nitidinerve is likely to be impacted by hydraulic actions (e.g. canalizations, deviations) that increase the water flow and thus reduce the availability of sediments (in particular mud) on the bed of watercourses, reducing micro-habitat suitability for larvae. The overexploitation of water resources is seriously harshened by anthropogenic climate change which has been impacting the Mediterranean basin during the last decades. In Mediterranean climates, the observed increase of warmer and dryer periods, together with the increasing water withdrawal, was reported to determine a general reduction and/or alteration of water resources, with major impacts on aquatic organisms, including dragonflies (Fenoglio, Bo, Cucco, Mercalli, \& Malacarne, 2010; Ott, 2010; Zacharias \& Zamparas, 2010). An increase in temperatures could be expected to foster a northern expansion of $O$. nitidinerve at the northern boundaries of its current range (Kalkman \& Garrigos, 2015), as reported for other African and Mediterranean species (Biella et al., 2017; Hassall \& Thompson, 2008; Janni, Viganò, \& Corso, 2020; Piretta \& Assandri, 2019; Polette et al., 2017; Rattu et al., 2014); however, to date, there is no evidence of this. 


\section{Genetic characterization and phylogenetic assessment}

Until recently, Orthetrum nitidinerve genetic diversity was unknown and the first sequences were produced in the framework of a COI-based comprehensive DNA barcoding survey of Italian odonates (Galimberti et al., 2020). In the present study, additional ITS sequences were generated, allowing a further characterization of the genetic diversity of the species.

JModelTest and PartitionFinder found slightly different best-fit evolutionary models according to the information criteria used (SM3), but the use of different models did not influence downstream analyses, resulting in highly similar phylogenetic trees. Likewise, the tree topologies of ML and BI analyses were highly consistent, therefore only ML trees are shown (Figure 6).

The phylogenetic analyses of the DS1 (all available Orthetrum COI sequences) included 29 out of the 65 currently recognized Orthetrum species (Schoor \& Paulson, 2020) and revealed that almost all species form monophyletic lineages, except for O. pruinosum (Burmeister, 1839), whose sequences in part clusters with O. testaceum (Burmeister, 1839) and in part forms a divergent lineage $(O$. pruinosum clelia (Selys, 1878)), and of the only sequence available of $O$. lineostigma (Selys, 1886), which clusters with O. brunneum sequences (Figure 6a). Orthetrum nitidinerve is nevertheless well separated from all other species for which a DNA barcode is available and appears to be a sister group of the O. brunneum/O. lineostigma lineage. Similarly, the analysis of COI genetic distances (SM4) supports the "genetic distinctiveness" of $O$. nitidinerve, since the average inter-specific genetic K2P-distances with other species range from $8.5 \pm 1.3 \%$ (O. nitidinerve-O. julia Kirby, 1900) up to $13.9 \pm 1.3 \%$ (O. nitidinerve-O. trinacria (Selys, 1841)), and these values are high and far above the optimal threshold (calculated on the 57 Italian Anisoptera species, of which six were Orthetrum spp.) of 1.96\% found by Galimberti et al. (2020).

The COI phylogenetic tree is characterized by high nodal supports at the species level, but deeper nodes are rarely resolved, due to the high variability of the COI region. For this reason, multi-locus phylogenetic analyses were performed including all the genetic information available for the genus. The resulting tree (Figure 6b) comprises fewer species than the single-locus analysis (13 out of 65), but the general statistical support of nodes is higher both in the terminal and deeper nodes. In both COI and multi-locus trees, $O$. nitidinerve appears to be closely related to $O$. lineostigma (and O. brunneum in the single-locus tree) and also the average genetic distances between $O$. nitidinerve and these two other species are among the lowest (SM4), further supporting a close relationship among these species.

Regarding the intraspecific diversity of $O$. nitidinerve, the two individuals included in the analyses were both collected in Sardinia and revealed to be identical in both COI and ITS regions, showing an intra-specific genetic distance equal to zero (SM4). The intra-specific genetic diversity of other Orthetrum species was also very low, except for a few species, in some cases already suspected to harbour cryptic taxa (e.g. Galimberti et al., 2020; Yong et al., 2014).

\section{Closing remarks and outcomes of the study}

This study summarizes all the knowledge on the Western Mediterranean endemic dragonfly $O$. nitidinerve available for Italy to date. It allowed confirmation that this dragonfly has never occurred in continental Italy and that past reports derived from erroneous identification of collection specimens and their subsequent "fixation" in literature. This possibly has conservation implications, as this evidence can impact the definition of the range size of the species according to criteria such as those adopted in the definition of IUCN red lists, which often base their evaluation on the extent of occurrence (i.e. range area). 


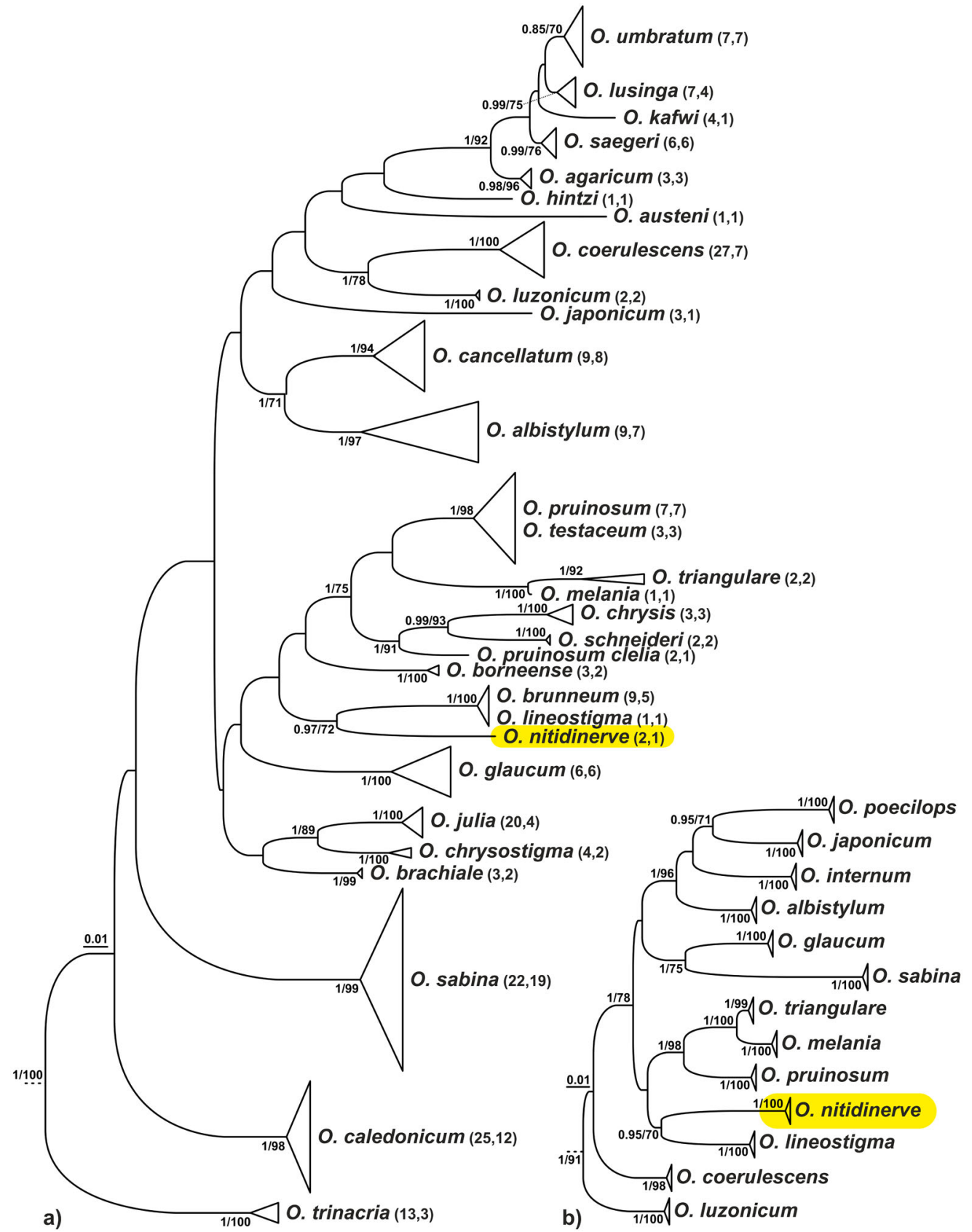

Figure 6. Phylogenetic hypotheses of the genus Orthetrum and putative placement of $O$. nitidinerve based on the a) COI dataset (DS1) and b) multi-locus dataset (DS2). Both trees depict ML topologies and numbers at nodes represent Bayesian posterior probabilities (BPP) and ML bootstrap supports (ML-BS), respectively. Values at nodes are shown only for BPP $\geq 0.9$ and ML-BS $\geq 70$. In the DS1 tree, numbers within brackets represent the number of sequences and haplotypes for each species. In both trees, $O$. nitidinerve lineages are highlighted in yellow. 
We are aware that several populations of the species could have been overlooked so far. Causes of this could be: (i) limited research in the known range of the species; (ii) difficulties in finding reproductive habitats that often occur in very homogenous agricultural landscapes and can be very limited in extension (a few metres), being often scarcely attractive for entomologists and dragonfly-watchers (Prunier, 2015); (iii) particular behaviour - in fact, according to Bucciarelli (1977) and Bucciarelli et al. (1983), the apparent rarity of the species can be possibly explained by its specific behaviour of returning to streams only in the afternoon (i.e. when the temperature decreases), which makes sightings less likely than in the case of other dragonflies. However, Prunier (2015) in southern Spain observed exactly the opposite behaviour, with the species most active in the hottest hours of the day, and the same applies to Sardinia (pers. obs.), thus we are confident that this last point scarcely influences the detectability of the species. This work also adds information on the genetic characterization and phylogeny of $O$. nitidinerve, facilitating its molecular identification in future studies, as well as laying the grounds for the understanding of the evolution of the species and the genetic structure and connectivity of the different populations. Additionally, our results allowed us to fill several knowledge gaps on the autecology of the species, and, most important, on the anthropogenic pressures and threats which have impacted it.

Overall, our understanding of the natural history of this dragonfly, one of the less studied among the odonate fauna of Europe, is still in its infancy, thus we advocate for further studies focusing on the distribution (with a specific focus on detecting breeding populations, which are likely still largely underestimated) and the habitat requirements of the species based on quantitative analyses. This will prove fundamental to correctly address and possibly counteract the decline Orthetrum nitidinerve is facing at the continental scale.

\section{Acknowledgements}

The authors are grateful to G. Boano (Museo Civico di Storia Naturale di Carmagnola), G. Carchini, C. D'Antonio, G. de Knijf, M. Pavesi (Museo Civico di Storia Naturale, Milano), F. Landi, N. Scatassi, and S. Surdo for sharing unpublished data, publications, and for useful comments. F. Ramazzotti and D. Magnani contributed to the genetic analyses at ZooPlantLab. Several records used for this study were derived from www.observation.org: we would like to thank the platform team. R. Improta and P. Cappelletti (Centro Musei delle Scienze Naturali, Università degli Studi di Napoli "Federico II") kindly facilitated the control of specimens conserved in the collection "A. Costa". GA would finally like to thank the friends of Odonata.it for constant support.

\section{Supplemental data}

Supplemental data for this article can be accessed here https://doi.org/10.1080/13887890.2020.1828194.

\section{Supporting information}

SM1. Alignment of the 206 COI sequences mined from GenBank and used to build DS1

SM2. List of the species included in DS2, with information on the specimen vouchers and GenBank accession numbers for the COI, 16S rRNA and ITS regions

SM3. Substitution models found for DS1 and DS2 according to the different information criteria. AIC = Akaike Information Criterion; AICc $=$ corrected AIC; BIC = Bayesian Information Criterion.

SM4. Pairwise comparisons of Kimura 2-parameter genetic distance within and between Orthetrum species based on the COI region. Interspecific pairwise comparisons are reported below the diagonal whereas the corresponding standard deviations are reported above the diagonal. Intraspecific distances ( \pm standard deviations) distances are indicated along the diagonal. Pairwise genetic distances between $O$. nitidinerve and other species are highlighted in yellow. n.c. $=$ not calculable. 


\section{Availability of data and material}

The dataset of the Italian occurrence and breeding sites of Orthetrum nitidinerve created for this study is available from the Figshare repository at https://doi.org/10.6084/m9.figshare.12136041.v1

\section{Author contributions}

GA conceived the idea and collected/reviewed the faunistic data. BK provided most of the unpublished data. GA and GB collected samples used for DNA analysis and revised specimens in Napoli. AG stored the biological tissues and performed the lab analyses. DM mined data from BOLD and GenBank and ran the genetic statistical analyses, with the help of AG. All authors contributed to check the final results. GA led the writing of the manuscript, supported by all authors, who critically contributed to the final version.

\section{ORCID}

Giacomo Assandri (DD http://orcid.org/0000-0001-5161-5353

Davide Maggioni (iD http://orcid.org/0000-0003-0508-3987

Andrea Galimberti (D) http://orcid.org/0000-0003-3140-3024

\section{References}

Batzer, D., \& Boix, D. (2016). Invertebrates in Freshwater Wetlands. In Invertebrates in Freshwater Wetlands (pp. 645). Cham, Switzerland: Springer.

Bentivoglio, T. (1905). Libellulidi dell'Italia Meridionale esistenti nel Museo Zoologico della R. Università di Napoli. Annuario Del Museo Zoologico Della Regia Università Di Napoli, 1, 1-12.

Biella, P., Bogliani, G., Cornalba, M., Manino, A., Neumayer, J., Porporato, M., \& Milanesi, P. (2017). Distribution patterns of the cold adapted bumblebee. Journal of Insect Conservation, 21, 357-366. https://doi.org/10.1007/s10841-017-9983-1

Borgwardt, F., Robinson, L., Trauner, D., Teixeira, H., Nogueira, A. J. A., Lillebø, A. I., \& Culhane, F. (2019). Exploring variability in environmental impact risk from human activities across aquatic ecosystems. Science of the Total Environment, 652, 1396-1408. https://doi.org/10.1016/j.scitotenv.2018.10.339

Boudot, J.-P., \& Kalkman, V. J. (Eds.) (2015). Atlas of the European dragonflies and damselflies. The Netherlands: KNNV Publishing.

Bucciarelli, I. (1977). Dati preliminari sul popolamento odonatologico di Calabria, Sicilia e Sardegna (VIII Contributo alla conoscenza degli Odonati). Annali Del Museo Civico Di Storia Naturale Di Genova, 81, 374-386.

Bucciarelli, I., Galletti, P. A., \& Pavesi, M. (1983). Attuali conoscenze sul popolamento odonatologico della Sardegna. Lavori della Società Italiana di Biogeografia, 8, 465-544.

Caraveli, H. (2000). A comparative analysis on intensification and extensification in mediterranean agriculture: dilemmas for LFAs policy. Journal of Rural Studies, 16, 231-242. https://doi.org/10.1016/S0743-0167(99)00050-9

Castresana, J. (2000). Selection of conserved blocks from multiple alignments for their use in phylogenetic analysis. Molecular Biology and Evolution, 17, 540-552. https://doi.org/10.1093/oxfordjournals.molbev.a026334

Collen, B., Whitton, F., Dyer, E. E., Baillie, J. E. M., Cumberlidge, N., Darwall, W. R. T., ... Böhm, M. (2014). Global patterns of freshwater species diversity, threat and endemism. Global Ecology and Biogeography, 23, 40-51. https://doi.org/10.1111/geb.12096

Conci, C., \& Galvagni, O. (1948). Odonati di Romagna (Coll. Zangheri). Memorie Della Società Entomologica Italiana, $27,72-76$

Conci, C., \& Nielsen, C. (1956). Fauna d'Italia Vol. 1. Odonata. Bologna: Calderini.

Consiglio, C. (1952). Odonati dell'Italia meridionale e degli Abruzzi. Memorie Della Società Entomologica Italiana, 31, 96-108.

Corso, A., Janni, O., Pavesi, M., Sammut, M., Sciberras, A., \& Viganò, M. (2012). Annotated checklist of the dragonflies (Insecta Odonata) of the islands of the Sicilian Channel, including the first records of Sympetrum sinaiticum Dumont, 1977 and Pantala flavescens (Fabricius, 1798) for Italy. Biodiversity Journal, 3, 459-478.

D’Antonio, C. (1985). Attuali conoscenze sul popolamento odonatologico della Campania (III contributo alla conoscenza degli Odonati). Bollettino della Società dei Naturalisti in Napoli, 94, 187-201.

D’Antonio, C. (1987). Gli Odonati del lago di Falciano (Falciano del Massico, Caserta) e nuove catture di Odonati in altre stazioni. Bollettino Della Società dei Naturalisti in Napoli, 96, 165-175.

D’Antonio, C. (1989). Contributo alla conoscenza degli Odonati. XXII. Gli Odonati della Collezione A. Costa. Bollettino della Società Entomologica Italiana, 121, 5-9.

D'Antonio, C. (1997). Odonate collection in the department of agricultural entomology and zoology of the university of Naples. Notulae Odonatologiche, 4, 137-152.

Darriba, D., Taboada, G. L., Doallo, R., \& Posada, D. (2012). jModelTest 2: more models, new heuristics and parallel computing. Nature Methods, 9, 772-772. https://doi.org/10.1038/nmeth.2109 
Darwall, W., Bremerich, V., De Wever, A., Dell, A. I., Freyhof, J., Gessner, M. O., \& Weyl, O. (2018). The Alliance for Freshwater Life: A global call to unite efforts for freshwater biodiversity science and conservation. Aquatic Conservation: Marine and Freshwater Ecosystems, 28, 1015-1022. https://doi.org/10.1002/aqc.2958

De Knijf, G., \& Demolder, H. (2010). Odonata records from Alentejo and Algarve, southern Portugal. Libellula, 29, 61-90.

Fenoglio, S., Bo, T., Cucco, M., Mercalli, L., \& Malacarne, G. (2010). Effects of global climate change on freshwater biota: A review with special emphasis on the Italian situation. Italian Journal of Zoology, 77, 374-383. https://doi.org/10.1080/11250000903176497

Galimberti, A., Assandri, G., Maggioni, D., Ramazzotti, F., Baroni, D., Bazzi, G., .. Casiraghi, M. (2020). Italian Odonates in the Pandora's Box: A Comprehensive DNA Barcoding Inventory Shows Taxonomic Warnings at the Holarctic Scale. Molecular Ecology Resources, in press. https://doi.org/10.1101/2020.04.23.056911

Gaona, J. M., \& Enrique, F. (2015). Nueva cita para la provincia de Cádiz (España) de Orthetrum nitidinerve (Selys 1941), (Odonata, Libellulidae). Boletín de la Sociedad Andaluza de Entomología, 25, 13-15.

Hall, T. A. (1999). BioEdit: a user-friendly biological sequence alignment editor and analysis program for Windows 95/98/NT. Nucleic Acids Symposium Series, 41, 95-98. https://doi.org/10.14601/PHYTOPATHOL_MEDITERR-14 998U1.29

Hassall, C., \& Thompson, D. J. (2008). The effects of environmental warming on Odonata: a review. International Journal of Odonatology, 11, 131-153.

Janni, O., Viganò, M., \& Corso, A. (2020). First records of Diplacodes lefebvrii (Rambur, 1842) for Sicily and additional record of Trithemis kirbyi Selys, 1891 (Odonata Libellulidae). Biodiversity Journal, 11, 65-68.

Jödicke, R., Arlt, J., Kunz, B., Lopau, W., \& Seidenbusch, R. (2000). The Odonata of Tunisia. International Journal of Odonatology, 3, 41-71. https://doi.org/10.1080/13887890.2000.9748135

Kalkman, V. J., Boudot, J.-P., Bernard, R., Conze, K.-J., De Knijf, G. De, Dyatlova, E., Ferreira, S., Jović, M., Ott, J., Riservato, E., \& Sahlén, G. (2010). European Red List of Dragonflies. Luxemburg: Publications Office of the European Union.

Kalkman, V. J., Boudot, J.-P., Bernard, R., De Knijf, G., Suhling, F., \& Termaat, T. (2018). Diversity and conservation of European dragonflies and damselflies (Odonata). Hydrobiologia, 811, $269-282$. https://doi.org/10.1007/s10750-017-3495-6

Kalkman, V. J., \& Garrigos, B. (2015). Orthetrum nitidinerve (Selys, 1841). In J.-P. Boudot, \& V. J. Kalkman (Eds.). Atlas of the European dragonflies and damselflies (pp. 281-283). The Netherlands: KNNV Publishing.

Katoh, K., \& Standley, D. M. (2013). MAFFT Multiple Sequence Alignment Software Version 7: Improvements in Performance and Usability. Molecular Biology and Evolution, 30, 772-780. https://doi.org/10.1093/molbev/mst010

Khelifa, R., Zebsa, R., Kahalerras, A., \& Mahdjoub, H. (2012). Clutch size and egg production in Orthetrum nitidinerve Selys, 1841(Anisoptera: Libellulidae): Effect of body size and age. International Journal of Odonatology, 15, 51-58. https://doi.org/10.1080/13887890.2012.682921

Khelifa, R., Zebsa, R., Moussaoui, A., Kahalerras, A., Bensouilah, S., \& Mahdjoub, H. (2013). Niche partitioning in three sympatric congeneric species of dragonfly, Orthetrum chrysostigma, O. coerulescens anceps, and $O$. nitidinerve: the importance of microhabitat. Journal of Insect Science, 13, 1-17. https://doi.org/10.1673/031.013.7101

Kumar, S., Stecher, G., Li, M., Knyaz, C., \& Tamura, K. (2018). MEGA X: Molecular evolutionary genetics analysis across computing platforms. Molecular Biology and Evolution, 35, 1547-1549. https://doi.org/10.1093/molbev/msy096

Lanfear, R., Calcott, B., Ho, S. Y. W., \& Guindon, S. (2012). PartitionFinder: combined selection of partitioning schemes and substitution models for phylogenetic analyses. Molecular Biology and Evolution, 29, 1695-1701. https://doi.org/10.1093/molbev/mss020

López-Estrada, E. K., Fernández, J. B., Cardo-Maeso, N., Teruek Montejano, S., \& Diaz-Martinez, C. (2020). Onychogomphus cazuma sp. nov. from Spain: molecular and morphological evidence supports the discovery of a new European dragonfly species (Odonata: Gomphidae). Odonatologica, 49, $125-154$. https://doi.org/10.5281/zenodo.3823337

Maddison, W. P., \& Maddison, D. R. (2018). Mesquite: a modular system for evolutionary analysis. Retrieved from http://www.mesquiteproject.org

Marquez-Rodriguez, J. (2014). Primera cita de Orthetrum nitidinerve (Selys, 1841) (Odonata: Libellulidae) en el Algarve (sur de Portugal). Arquivos Entomoloxicos, 10, 65-68.

Márquez-Rodríguez, J., \& Ferreras-Romero, M. (2013). Orthetrum nitidinerve in the southern Iberian Peninsula: two breeding populations in the Seville Province (Odonata: Libellulidae). Libellula, 32, 141-149.

May, M. (2019). Odonata: who they are and what they have done for us lately: classification and ecosystem services of dragonflies. Insects, 10, 62. https://doi.org/10.3390/insects10030062

Mazzamuto, M. V., Galimberti, A., Cremonesi, G., Pisanu, B., Chapuis, J.-L., Stuyck, J., \& Martinoli, A. (2016). Preventing species invasion: A role for integrative taxonomy? Integrative Zoology, 11, $214-228$. https://doi.org/10.1111/1749-4877.12185

Miller, M. A., Pfeiffer, W., \& Schwartz, T. (2010). Creating the CIPRES Science Gateway for inference of large phylogenetic trees. 2010 Gateway Computing Environments Workshop (GCE), 1-8. https://doi.org/10.1109/GCE.2010. 5676129

Nielsen, C. (1940). Odonati di Sardegna. Memorie Della Società Entomologica Italiana, 19, 235-258.

Ott, J. (2010). Dragonflies and climatic change - recent trends in Germany and Europe. BioRisk, 5, 253-286.

Piretta, L., \& Assandri, G. (2019). First record of the migrant dragonfly Pantala flavescens for mainland Italy (Insecta: Odonata). Fragmenta Entomologica, 51, 247-250. https://doi.org/10.4081/fe.2019.376 
Plieninger, T., Hui, C., Gaertner, M., \& Huntsinger, L. (2014). The impact of land abandonment on species richness and abundance in the Mediterranean Basin: A meta-analysis. PLOS ONE, 9(5). https://doi.org/10.1371/journal.pone. 0098355

Polette, P. P., Abbott, C., Gouys, J., Jenard, P., Juliand, P., Darnaud, S., \& Boudot, J. (2017). Premières mentions de Trithemis kirbyi (Odonata: Libellulidae) en France. Martinia, 33(June), 15-25.

Prunier, F. (2015). Nueva población de Orthetrum nitidinerve en Córdoba. Boletin Rola, 5, 25-36.

Rattu, A., Leo, P., Moratin, R., \& Hardersen, S. (2014). Diplacodes lefebvrii in Sardinia, a new species for the Italian fauna (Odonata: Libellulidae). Fragmenta Entomologica, 46, 121-124.

Riservato, E., Boudot, J.-P., Ferreira, S., Jović, M., Kalkman, V. J., Schneider, W., \& Cuttelod, A. (2009). The status and distribution of dragonflies of the Mediterranean basin. Gland, Switzerland: IUCN.

Riservato, E., Fabbri, R., Festi, A., Grieco, C., Hardersen, S., Landi, F., \& Utzeri, C. (2014a). Lista rossa IUCN delle Libellule Italiane. Roma: Comitato italiano IUCN e Ministero dell' Ambiente e della Tutela del Territorio e del Mare.

Riservato, E., Festi, A., Fabbri, R., Grieco, C., Hardersen, S., La Porta, G., \& Utzeri, C. (2014b). Odonata - Atlante delle libellule italiana - preliminare. Società per lo Studio e la Conservazione delle Libellule. Latina: Edizioni Belvedere.

Ronquist, F., Teslenko, M., van der Mark, P., Ayres, D. L., Darling, A., Höhna, S., \& Huelsenbeck, J. P. (2012). MrBayes 3.2: efficient Bayesian phylogenetic inference and model choice across a large model space. Systematic Biology, 61, 539-542. https://doi.org/10.1093/sysbio/sys029

Schoor, M., \& Paulson, D. (2020). World Odonata List. Retrieved March 31, 2020, from https://www.pugetsound.edu/ academics/academic-resources/slater-museum/biodiversity-resources/dragonflies/world-odonata-list2/

Sciberras, A., \& Sammut, M. (2013). The occurrence of the Copper Emerald Calopteryx haemorrhoidalis (Vander Linden, 1825), records of rare species, changing population trends of some hitherto common species and recent colonisers in the Maltese Islands. Journal of the British Dragonfly Society, 28, 1-9.

Sciberras, A., Sciberras, J., \& Kunz, B. (2010). Orthethrum nitidinerve new to the Maltese Islands (Odonata: Libellulidae). Libellula, 29, 55-60.

Selys, E. (1841). Nouvelles libellulidéees d'Europe. Revиe Zoologique, 4, $243-246$.

Selys, E., \& Hagen, H. A. (1850). Revue des Odonates ou Libellules d'Europe. Paris: Roret.

Sirami, C., Brotons, L., Burfield, I., Fonderflick, J., \& Martin, J. (2008). Is land abandonment having an impact on biodiversity? A meta-analytical approach to bird distribution changes in the north-western Mediterranean. Biological Conservation, 141, 450-459. https://doi.org/10.1016/j.biocon.2007.10.015

Sokos, C. K., Mamolos, A. P., Kalburtji, K. L., \& Birtsas, P. K. (2013). Farming and wildlife in Mediterranean agroecosystems. Journal for Nature Conservation, 21, 81-92. https://doi.org/10.1016/j.jnc.2012.11.001

Spagnolini, A., \& Ragazzi, V. (1879). Nota delle libellule raccolte nelle campagne livornesi e pisane nei mesi di estate e autonno 1873-1876. Bollettino Della Società Entomologica Italiana, 11, 68-72.

Stamatakis, A. (2014). RAxML version 8: a tool for phylogenetic analysis and post-analysis of large phylogenies. Bioinformatics, 30, 1312-1313. https://doi.org/10.1093/bioinformatics/btu033

Strayer, D. L. (2006). Challenges for freshwater invertebrate conservation. Journal of the North American Benthological Society, 25, 271-287.

Surdo, S. (2017). First record of Lindenia tetraphylla (Vander Linden, 1825) and rediscovery of Orthetrum nitidinerve (Selys, 1841) in Sicily (Insecta: Odonata). Fragmenta Entomologica, 49, 185. https://doi.org/10.4081/fe.2017.263

Talavera, G., \& Castresana, J. (2007). Improvement of phylogenies after removing divergent and ambiguously aligned blocks from protein sequence alignments. Systematic Biology, 56, 564-577. https://doi.org/10.1080/106351507014 72164

Termaat, T., van Strien, A. J., van Grunsven, R. H. A., De Knijf, G., Bjelke, U., Burbach, K., ... WallisDeVries, M. F. (2019). Distribution trends of European dragonflies under climate change. Diversity and Distributions, 1-15. https://doi.org/10.1111/ddi.12913

Torralba Burrial, A., Ocharan Larrondo, F. J., Cano Villegas, F. J., Outomuro Priede, D. Azpilicueta Amorín, M. (2011). Orthetrum nitidinerve (Selys, 1841). In J. R. Verdú, C. Numa, \& E. Galante (Eds.), Atlas y Libro Rojo de los Invertebrados amenazados de España (Especies Vulnerables) (pp. 588-594). Madrid: Dirección General de Medio Natural y Política Forestal, Ministerio de Medio Ambiente, Medio Rural y Marino.

Viganò, M., Janni, O., \& Corso, A. (2017). Tramea basilaris on Linosa Island, Italy: A new species for Europe and the Western Palaearctic (Odonata: Libellulidae). Odonatologica, 46, 55-66. https://doi.org/10.5281/zenodo.572356

Villesen, P. (2007). FaBox: an online toolbox for fasta sequences. Molecular Ecology Notes, 7, 965-968. https://doi.org/10.1111/j.1471-8286.2007.01821.x

Weekers, P. H. H., De Jonckheere, J. F., \& Dumont, H. J. (2001). Phylogenetic relationships inferred from ribosomal ITS sequences and biogeographic patterns in representatives of the genus Calopteryx (Insecta: Odonata) of the West Mediterranean and adjacent West European Zone. Molecular Phylogenetics and Evolution, 20, 89-99. https://doi.org/10.1006/MPEV.2001.0947

Yong, H. S., Lim, P. E., Tan, J., Ng, Y. F., Eamsobhana, P., \& Suana, I. W. (2014). Molecular phylogeny of Orthetrum dragonflies reveals cryptic species of Orthetrum pruinosum. Scientific Reports, 4, 1-9. https://doi.org/10.1038/srep05553

Zacharias, I., \& Zamparas, M. (2010). Mediterranean temporary ponds. A disappearing ecosystem. Biodiversity and Conservation, 19, 3827-3834. https://doi.org/10.1007/s10531-010-9933-7 